\title{
Stüdyo kayıt ortamında karşılaşılan performans kaygısı ve anksiyete sendromunun çalgı icracılarının bașarıları üzerindeki olumsuz etkileri
}

\author{
Hakan Emre Ziyagil* \\ *Sorumlu yazar: Gazi Üniversitesi, Müzik, Eğitim Bilimleri Fakültesi, Ankara, Türkiye. \\ hakanemreziyagil@gmail.com, https://orcid.org/0000-0002-2981-2497
}

DOI 10.12975/rastmd.2021914 Submitted May 9, 2021 Accepted July 26, 2021

\section{Özet}

Günümüz müzik sektörüne ve gelișimine bakıldığında gerek albüm kayıtlarında ve gerekse konser performanslarında çalgı icracılarının büyük bir öneme sahip oldukları görülmektedir. Çalgı icracıları, bireysel performanslarını en iyi șekilde sunmak ve hatasız bir șekilde çalmak adına yoğun bir șekilde zaman harcamaktadırlar. Fakat harcamıș oldukları bu zaman sonunda ortaya çıkan performansı, stüdyo ortamlarında istenilen düzeyde sergileyememektedirler. Çalgı icracılarının yașadıkları bu sorunların nedeni kendi kaygıları ile huzursuzlukları olabilmekte ve bu da icralarını olumsuz yönde etkileyebilmektedir. Profesyonel ya da amatör icracıların en büyük sorunlarından birisi olarak göze çarpan bu duruma genel olarak "Performans Kaygısı" da denilmektedir. Özellikle stüdyo ortamındaki ses kayıt seanslarında müzisyenlerin çalgılarını hatasız bir șekilde icra etmeleri beklenmektedir. Bu beklenti, çalgı icra eden müzisyenleri baskı altına almakla birlikte üzerlerinde bariz bir tedirginlik hâli de olușturmaktadır. Bu anlamda icracılar her ne kadar profesyonel bir kimlikte olsa dahi beklenmedik olumsuz durumlarla karșı karșıya kalabilmektedirler. Tüm bu olumsuz durumlar, bir eser icrası sırasında ya da stüdyoda kayıt altına alınan albüm parçalarında anlık olarak meydana gelen yanlıș nota baskıları veya strese bağlı yanlıș nota okuma dürtüsü ile bașa çıkamama gibi olgulardır. Stüdyo ortamları genelde icracıların çalgıları ile baș bașa kaldıkları ve performanslarıyla da tüm müzikal birikimlerini ve tecrübelerini yansıttıkları alanlardır. Bu çalıșmanın amacı, çalgı icracılarının stüdyo ortamlarında kendilerinden beklenen yüksek düzeydeki hatasız performans seansları sırasında karșılaștıkları problemleri ortaya koymak ve bu problemlere çözüm bulmaktır. Aynı zamanda bu araștırmada konuyla ilgili verilerin toplanması amacıyla nitel araștırma yöntemlerinden tarama (Survey) modeli kullanılmıștır. Araștırma sonucunda ulașılan veriler betimsel analiz yönteminden yararlanılarak yorumlanmıș ve bu bağlamda çeșitli önerilerde bulunulmuştur.

\section{Anahtar kelimeler}

çalgı İcrası, stüdyo kayıt ortamı, performans kaygısı, anksiyete

Müzisyenlerin, özellikle de çalgı icracılarının yașamları boyunca performanslarını en üst seviyeye çıkarmaları hem vazgeçilmez hem de en istenen olgular arasında yer almaktadır. Gerek müzik eğitimi boyunca ve gerekse bireysel eğitim sonucunda ortaya çıkan çalgı performansının en doğru ve de en verimli bir șekilde dinleyenlere ya da izleyicilere aktarılması, bir çalgı icracısı için hedeflenen en önemli amaçlar arasında yer almaktadır. Bu hedeflenen amaçları ele aldığımızda bu duruma bağlı olarak ortaya bazı olumsuz unsurlar da çlkabilmektedir. Bu olumsuz unsurlar; stres, kaygı ve korku gibi kavramlardır. Sağlıklı bir çalgı icracısında bile anksiyeteye bağlı bu tür durumlar ortaya çıkabilmektedir. Bir müzisyenin icra sırasında ortaya koyacağı performansın en iyi șekilde 
olabilmesi için ruh sağlığının da yerinde olması ve buna bağlı olarak da psikomotor becerilerinin olumlu etkilenmesi gerekmektedir (Williamon, 2004:.8).

Stüdyo ortamları genelde profesyonel müzisyenlerin kayıt yaptığı alanlar olarak bilinmektedir. Bu ortamlar, özellikle de çalgı icracılarının kendi performanslarını en yüksek düzeyde sergiledikleri alanlardır. Dolayısıyla da icracının her zaman en iyi performansı sergileme dürtüsünü kendisinde barındırmaktadır. Bu durum, aşırıya kaçıldığında çalgıyı icra eden müzisyenin kaygisının artmasına neden olmaktadır. Kendi özgür alanında (evde ya da rahat bir ortamda) çok rahatlıkla çalmıș olduğu bir eseri (notasyonu), stüdyo ortamında aynı performansla çalamama gibi durumların ortaya çıkması nedeniyle kaygı ya da anksiyete ile sonuçlanmaktadır. Bu kaygılar "sahne kaygısı" başlığı altında toplansa da bireysel olarak nitelendirildiğinde "performans kaygısı" kavramının çalgı icracıları adına daha anlamlı olduğu düşünülmektedir. Bireysel olarak yapılan performanslarda, icracı kendisini daha fazla stres altında hissetmektedir. Aksine, toplu yapılan icralarda ise kiși sayısının artmasından dolayı icracıların kaygı düzeyinin azaldığı gözlemlenmiștir (Parncutt ve McPherson, 2002).

Genel olarak düșünüldüğünde "heyecan" kelimesi ile anksiyete (kaygı, tasa) kelimeleri müzisyenler tarafından aynı șekilde dile getirilse de literatür açısından tam olarak birbirini karşılamamaktadır. $\mathrm{Bu}$ problem dünya literatüründe "Musical Performance Anxiety" olarak adlandırılmaktadır (Teztel ve Așkın, 2007). Profesyonel anlamda çalgı çalan ve stüdyo kayıtlarına giren müzisyenlerin genelinde "heyecan" olarak tabir ettikleri performans anksiyetesi görülebilmektedir. Hatta bazı icracılar bu heyecan hissinin yükselmesini faydalı olarak görmekle birlikte icra performansına pozitif bir katkı sağladığı konusunda da hem fikir olduklarını dile getirmişlerdir (Steptoe, 1989).

Çalgı icracılarının performanslarında meydana gelen olumsuz ya da olumlu unsurlar ele alındığında, kendi kișisel durumlarının da etkili olduğu gözlemlenmektedir. Örneğin; içe dönük ve duygusal bir yapıya sahip olan müzisyenlerin, dișa dönük olan müzisyenlere nazaran daha hassas oldukları ve kaygı düzeylerinin de daha yüksek olduğu bilinmektedir (Salmon, 1990). Öte yandan bazı müzisyenlerin mükemmeliyetçi olmaları ve kontrol mekanizmalarının așırı çalıșması nedeniyle sahne kaygısı (yani stüdyo stresi) ile de bağlantılı bir ilișki olduğu saptanmıștır (Parncutt ve McPherson, 2002).

\section{Anksiyete, SAB ve DEHB'in Çalgı}

İcracıları ile Olan İlișkisi

Anksiyete sözcüğünün kökenine bakıldığında, Fransızca (anxiété) tabanlı olmakla birlikte kaygı, sıkıntı, sebebi belli olmayan korku ve dürtü anlamlarına geldiği görülür. Fransızcada kullanılan "anxiété" sözcügüu ise Latincede de aynı karşılığı ve anlamı içeren "anxietas" sözcüğünden alıntılanmıștır. Latincedeki karșılığı ise daraltmak, boğmak ve sıkmak anlamlarına gelirken "angree" fiilinden türetilen bir sözcük yapısıdır (Anksiyete, 2021).

Anksiyete (kaygı); hoș olmayan bir iç çalıșma durumu ile karakterize edilen, slk bir şekilde ileri - geri ilerleme gibi 
sinirsel davranıșların eșlik ettiği bir duygu biçimidir. Anksiyete ayrıca kavramsal, duygusal, somatik ve davranıșsal bileșenlere sahip olmak biçiminde de tanımlanabilir (Seligman, Walker ve Rosenhan, 1989). Anksiyete (endișe) davranıșının en önemli özellikleri ise duygusal ifade olarak panik ve korku hissinin ortaya çıkmasıdır. Kan basıncının (tansiyon) yükselmesi, kalp ritminin (Bpm) hızlanması, ellerin terlemesi ve soğuması, kan akışının hızlanması nedeniyle kaslarda meydana gelen gerginlik, bağışıklık sistemi ile sindirim sisteminde meydana gelen bozukluklar (yavașlamalar), midenin bulanması ve titreme gibi birçok fiziksel reaksiyon anksiyete sırasında gözlemlenmektedir.

Anksiyete bozuklukları arasında en yaygın olanlarından birincisi "Sosyal Anksiyete Bozukluğu (SAB)" olarak bilinmektedir. SAB'ı kısaca açıklayacak olursak; "Kişinin tanımadığı insanlarla karșılaștığı, bașkalarının gözünün üzerinde olabileceği bir ya da birden fazla toplumsal durumdan belirgin ve sürekli bir korku duyması, küçük duruma düșeceği ya da utanç duyacağı bir biçimde davranacağından korkması ve anksiyete belirtileri göstermesidir. Korkulan toplumsal durumlardan kaçınılması ya da yoğun anksiyete ile buna katlanılması söz konusudur" (Koyuncu ve Binbay, 2014:11). “Anksiyete sonucunda bir müzisyenin, motor duygusal ve düșünsel fonksiyonları olumsuz yönde etkilenebilir. Performans anksiyetesinin semptomları olayla doğrudan bağlantılı olmayabilir. Performanstan haftalar önce ya da sonra ortaya çıkabilir. Performans anksiyetesinden șikayetçi olan kișiler, hastalığa yatkınlık ve iritasyon gösterirler" (Gidergi Alptekin, 2012).
Anksiyete bozuklukları arasında en yaygın olanlarından ikincisi ise "Dikkat Eksikliği Hiperaktivite Bozukluğu (DEHB)" olarak tanımlanmaktadır. DEHB ele alındığında ortaya 3 farkl fonksiyonel belirti çıkmaktadır. Bu belirtiler; "Dürtüsellik”, "Hiperaktivite" ve bu bozukluğun en belirleyici özelliği olan "Dikkat Eksikliği" olarak ortaya çıkmaktadır. Çalgı icracılarında sıkça gözlemlenen sorunlardan birisi olan "Dikkat Eksikliği”, icraya doğrudan etki etmekle birlikle olası konsantrasyon bozukluklarında olumsuz bir unsur olarak kendini göstermektedir. Konsantrasyon bozukluğu ise anksiyete sırasında hissedilen olgular arasında yer almaktadır. Anksiyete sırasında hissedilen diğer olgular ise; uyku bozuklukları, korku, sinir hali, huzursuzluk hissi ve kaslarda olușan kasılma (gerginlik) olarak da karşımıza çıkmaktadır.

\section{Çalgı İcracılarında Konsantrasyon Bozukluğu ve Performans Kaygısı} bakıldığında Müzikle uğraşan ve özellikle herhangi bir çalgı çalan bireylerde sıklıkla görülen bir durumdur. "Zihnin, uyaranlara karșı sürekli olarak tepki vermesi ve o ana odaklanamamasına konsantrasyon bozukluğu adı verilir" (Konsantrasyon Bozukluğu Nedir, 2021).

Özellikle de stüdyo ve konser aşamalarında ve odak gerektiren performanslarda heyecan unsuru ile birlikte konsantrasyon bozuklukları ani bir şekilde ortaya çıkmaktadır. Bunun nedenlerinin arasinda hata yapma korkusu, yanlıș nota basma korkusu, konser esnasinda seyircilerin bakıșlarının çalgı çalan icracının kendi üzerinde yaratmıș olduğu stres, stüdyo aşamasında kulaklıktan gelen metronom sesi ile yașanacak olan senkron kayması düșüncesi, notaya bakıp çalarken ortaya 
çıkacak olan yanlıs perde seslendirmesi gibibirçok unsur konsantrasyon bozukluğu durumunu ortaya çıkarmaktadır. Odaklanma sorunları ile meydana gelen bu sorun DEHB (Dikkat Eksikliği Hiperaktivite Belirtileri) konusunun içinde yer almaktadır. "Dikkatsiz DEHB" olarak da adlandirılan bu durum genel anlamda "odaklanamamak", "ayrıntılara dikkat edememek" ve "dikkatin kolay dağılması" gibi unsurları da içerisinde barındırmaktadır. Aynı zamanda konsantrasyonu etkileyen en belirgin olumsuz özellik ise "kișisel takıntılar" olarak karşımıza çıkmaktadır. Bireyin evhamlı bir șekilde kendisinde devaml takıntı haline getirmiş olduğu ve tekrar halini alan içsel söylemler, bu takıntıyı destekleyerek belirli bir çalgının icrası sırasında odağın ve konsantrasyonun dağılmasına neden olmaktadır.

Wilson'a göre müzisyenlerde korku ve kaygı probleminin ortaya çıkmasındaki ana eylemler șu șekilde sıralanmıștır (Wilson, 2002):

- Kayit veya konser esnasinda çalınacak olan nota (eser/ eserlerin) zorluk derecesi

- Kișinin durumuna bağlı olarak ortaya çıkan stres algısı (icra alanları vs.)

\section{- $\quad$ Tekrar eden kaygı faktörü}

Çalgı çalma (icra) oldukça karmaşık bir eylem olduğu için en küçük bir dikkatsizlik anının bile hata yapmaya yol açtığı görülmektedir. Bu hataları birçok profesyonel müzisyen de yapmaktadır. Fakat esasen bu hataları giderecek olan kișisel kontrol mekanizmasını sanatçının kendi bünyesinde geliștirmiş olması gerekir. Bu gereklilik, profesyonel çalgı icracılarının gerek stüdyo ve gerekse konser performanslarındaki başarı çıtasını oldukça üst sıralara taşımalarını sağlayacaktır. Bir müzisyenin (yani çalgı icracısının) bașka bireylerin önünde (konser salonu ve stüdyo gibi ortamlarda) ya da bir albüm kaydı için çalarken ortaya koyacağı performans, mutlaka kaygıyı da ortaya çıkarmaktadır. Bu kaygı kimi bireylerde (çalgı icracılarında) kontrol altına alınıp üstesinden gelinirken, kimisinde de kaygının dozu artmakla birlikte heyecan ve dikkat dağınıklığı da meydana gelmektedir. Bu duruma da genel olarak "Performans Kaygisı" denilmektedir. "Performans kaygısı neredeyse her yaș ve her yetenek grubundan insanı etkileyen önemli bir kaygı problemidir" (Eğilmez, Aytekin ve Dirican, 2013; Fishbein ve ark., 1998; Kenny ve Osborne, 2006; Sadler ve Miller, 2010; Salmon, 1990, aktaran Çırakoğlu, 2013).

Çalgı icracılarında anksiyeteye bağlı olarak ortaya çıkan "Performans Kaygısı" kavramının belli bir düzeyde olması, performans sirasinda motivasyonu arttırıcı olumlu bir eylem olarak karşımıza çıkabilmektedir. Fakat bu düzey belli bir sınırı așarak, icracının kendisini kontrol edemez bir hale gelip var olan performansını da etkilemeye başladığı anda sorunlar ortaya çıkmaktadır. Bu bağlamda ortaya çıkan performans kaygısının bir çeșit kaygı bozukluğu olduğu da söylenebilir (Aydın ve İșgörür, 2018). Çalgı icracılarının belli bir düzeye kadar hissetmiş oldukları "Performans Kaygısı" icra üzerinde olumlu bir fayda sağlarken, daha fazlasının hissedilip hastalık derecesinde yașanması arasındaki ayrım ise kaygı hissiyatının așırı derecede hissedilmesi 
halinde bașlamaktadır (Brotons, 1994, s.64).

Performans kaygılarının belirtilerini 3 ana bașlık halinde sıralamak mümkündür (Tokinan, 2013).

\section{- Davranıșsal}

- Fizyolojik

- Bilișsel

Davranıșsal olarak en çok görülen belirtiler arasında kaygılı bir yüz ifadesi, konsantrasyonun bozulması (tedirginlik), icra edilen eserde meydana gelen hataların ortaya çıkması ve konuşma sırasında seste ortaya çıkan titreme gibi olgular yer almaktadır.

Fizyolojik olarak ise; her icracida sıklıkla rastlanan ve heyecan unsuru ile birlikte ortaya çıkan kalp ritminin giderek hılanması, nefes alma ve verme sıklığının artması, baskı altında olunduğundan dolayı terleme, kaslarda meydana gelen gerilmeler (özellikle de el kaslarında) ve avuç içleri ile parmakların aşırı terlemesi gibi tipik semptomlar gözlemlenmektedir.

Bilișsel belirtilerde genel olarak; eseri icra edecek olan kișinin kaygısından dolayı ortaya çıkacak olan stresi kontrol altına alamaması ve konsantrasyon kaybına uğraması, eser icrası sırasında hata yapma korkusu, notayı ya da eseri çalarken dikkatin bir anda dağılması ve eserin unutulması gibi birçok durum meydana gelmektedir.

Kenny'egöre, çalgı icracılarında meydana gelen performans kaygıları bağlamında; müzik performansları kișinin kendisinde oluşan ayrıntıya dayalı motor yetilerini, bilișsel, estetik, hafıza ve yorumlama gibi iyi eğitilmiş becerileri dahil eden kompleks bir aşama olması nedeni ile yüksek düzeydeki müzik performansı kaygısı, o anda performansı ortaya koyan icracının (sanatçının) bireysel bașarısına zarar verme durumunu ortaya çlkarabilmektedir (Kenny, 2004:760). Aynı zamanda herhangi bir çalgıyı icra eden bireyde davranıș anlamında ortaya çıkan bir takım bozukluklar da meydana gelmektedir. Bu bozukluklar; performans sırasında ortaya çıkan hatalar, kaçınma psikolojisi, motor huzursuzluk, panikleme hali, dikkat dağınıklığı ve omuzların gereğinden fazla yukarıda kalkık bir vaziyette olması șeklinde belirti göstermektedir (Kafadar, 2009; Tokinan, 2013).

Müzik performansı kaygısının diğer bir tanımı ise, dinleyici karșısında (stüdyo ortamında ya da konser sırasında) icra edilen esere dair meydana gelen performansin bozulması ya da bu performansa dair devamlı bozulacak endișesi yașayan bir kișinin, eğitim, yetenek ve hazırlık süresi göz önünde bulundurularak açıklanamayacak ölçüde bir endișe duyması hali olarak da dile getirilebilir (Valentine, 2003). Valentine'nin üzerinde durmuș olduğu bu kaygı durumu günümüz çalgı icracılarında sıklıkla ortaya çıkan ve gözlemlenen bir durumdur. Yalnızca bir çalgıyı tek bașına iyi bir șekilde icra etmek yeterli olmamakla birlikte, bu icrayı toplum önünde ve stüdyo gibi yüksek performans gerektiren ortamlarda da iyi bir șekilde sergilemek gerekmektedir. Dolayısıyla da müzikal performans kaygısıyla birlikte her bireyin kendi benliğini de kontrol altına alması gerekmektedir. 
Profesyonel

anlamda

kanıtlamış çoğu çalgı icracısında görülen ana sorunlardan birisi de "Hata yapmamalıyım!" kurgusu ve düşüncesidir.Bu düșünce devamlı içsel olarak, icra esnasında bile tekrar edilerek bilinç altında aktif bir șekilde kendisini yinelemektedir. Bu durum dozunda olduğu zaman ve otokontrol sağlandığında gerekli ve yararlı olarak avantaj sağlarken, bu düșüncenin fazlası kișide oluștuğunda yıkıcı bir hale gelmektedir. Saatlerce hatta haftalarca çalıșılmış bir eserin ya da albüm parçalarının gereksiz stres algısı yüzünden heba edilmesi duygusu bir icracl için en kötü senaryolardan birisidir. Böylesi olumsuz bir durumla karșı karșıya kalınması, çalgı icracısının normal hayatının akıșını etkilemesine kadar giden zorlu bir süreci de ortaya koyabilmektedir (Kabakçı, 2016).

Çalgı icracılarında görülen stres algısına ve performans kaygısına yenik düșen birçok ünlü sanatçı bulunmaktadır. Bunlardan bazılarına örnek verecek olursak; dünyaca ünlü Kanadalı piyanist Glenn Gould, kendi konserlerinde yașamış olduğu performansına dair meydana gelen kaygısı yüzünden yaklașık 18 yıl süresince sahneleri bırakıp yalnızca kayıtlara çalmıștır. Hatta bu sendromu yüzünden hayatı boyunca ilaç kullanmak zorunda kaldığı da bilinmektedir. Performans kaygısı ile mücadele eden diğer bir müzisyen ise opera sanatçısı Renee Fleming'dir. Ayrıca Steven Osborne, Leopold Godowsky ve Vladimir Horowitz gibi dünyaca ünlü sanatçıları da bu durum içinde sayabiliriz (Cemali, 2017:1).
Stuidyo Kayıt Ortamındaki

Performans Kaygısı ve Anksiyete

Sendromunun Çalgı İcracıları

Üzerindeki Etkileri

Profesyonel müzisyenlerin ve özellikle çalgı icracılarının stüdyo aşamasında karșılaștıkları en büyük sorunlardan biri ortaya çıkan anksiyetedir. Bu anksiyete ile ortaya çıkan duruma "Performans Anksiyetesi" de denilebilmektedir. Performans anksiyetesi Gidergi Alptekin'e göre “Kişinin kendine güvenini sınayan bilinçaltı bir savunma mekanizması olup, kapasitesinin altında çalmasını sağlar. Üzüntünün, diğer kișilerin reaksiyonlarının ve rahatsız edilmenin sahne korkusu ile ilișkili olduğu ispatlanmıștır. Anksiyetenin, performansın düșünsel bölümünün en önemli kısmı olduğu tespit edilmiștir" șeklindeki ifadeleri ile ortaya koymuștur (Gidergi Alptekin, 2012:138). Genelde stüdyo ortamlarında sıklıkla karşımıza çıkan "Performans Anksiyetesi" çoğu icracının devamlı karșı karșıya kaldığı bir sorun olmuștur. Aynı zamanda diğer bir tanımlama olarak karşımıza "Müzik Performans Stres Sendromu" da çıkmaktadır (Salmon, 1990). Solmon'un üzerinde durmuș olduğu bu stres sendromu her müzisyenin ve özellikle stüdyoda kayıtlara giren icracıların en büyük düșmanı olmaktadır. Stüdyo aşamasında yapılacak olan kayıtlarda sıfır hataya yakın sonuçlar istenildiğinden dolayı çalgıyı icra eden müzisyenin üzerindeki stres sendromu oldukça baskın gelmektedir. Müzik performans stres sendromu ile başa çıkan birçok icracl bu stresi kontrol altına aldıklarında daha rahat ve daha üretken bir halde stüdyo kayıt așamasını tamamlamaktadır. Aksi halde bu sendroma yenik düșen çalgı icracıları kayıt esnasında birçok stres algısı ile 
karşı karşıya kalıp performanslarından ödün vermektedirler. Bu ödünler sonucu kayıt yapılacak olan eser ya da albüm parçalarının zamanında bitmemesi, sürenin uzaması ve bazen de tamamen çalamama, kayıttan vazgeçme gibi durumlarının ortaya çıkmasına neden olmaktadır. Bu tarz sendrom ve anksiyete panikle ortaya çıkmakla birlikte performans anksiyetesi denilen durum ise daha karmașık bir evredir (Weisblatt, 1986).

Bir icracının stüdyo ortamında karşı karşıya kaldığı müzik performans anksiyetesi (MPA) konusunda Gidergi Alptekin, "Müzik performans anksiyetesi, (MPA) müzik performansı sırasında ortaya çıkan afektif, kognitif, somatik ve davranışsal semptomlardan olușur. Genelde yüksek ego ve değerlendirilme durumlarında ortaya çıkar. Fokal ya da bașka anksiyete rahatsızlıklarıyla birlikte (sosyal fobi) seyredebilir. Müzisyenleri hayatları boyunca etkiler, müzik performans kalitelerini ise etkiyebilir ya da etkilemeyebilir" şeklindeki ifadeleri ile tanımlamaktadır (Gidergi Alptekin, 2012:139).

Stüdyo ortamında herhangi bir kayıtta çalınacağı (icra edileceği) sırada, çalan kișinin icra ettiği enstrümanı ile tam ve doğru olarak kayıt alması beklenmektedir. $\mathrm{Bu}$ düșüncenin beyinde ve düșünce sisteminde sürekli olușmasından dolayı ortaya çıkan anlık stres algısı ise çalgı icra eden müzisyeni olumsuz yönde etkilemektedir. Yukarıda da bahsettiğimiz gibi, burada ortaya çıkan müzik performans sendromu ile bașa çıkmak en önemli etkenler arasında yer almaktadır. Stüdyo kayıtlarında olușan bu anksiyete problemlerinin mutlaka giderilmesi gerekmektedir. Aksi halde stres baskısı ve konsantrasyon bozukluğu artarak o anki kayıtta çalan icracının yanlış yapma olasılığı oldukça artacaktır. Bu anlamda stüdyo performanslarında ortaya çıkan birkaç semptom göze çarpmaktadır. Bu semptomlardan bazıları; bașarısız olma dürtüsü, kişinin içindeki şüphe duygusu ve kendisinde var olan fiziksel (el terlemesi, nefes alıp verme sorunları, kalp ritminin hızlanması) sorunlar ortaya çıkmaktadır.

Stüdyo performanslarında ortaya çıkan anksiyete ve kaygılar, aynı zamanda "sahne korkusu" olarak adlandırılan bir diğer bașlık ile de paralel bir yapı içerisinde düșünülebilir. Zira sahne korkusu ile stüdyo performansı arasında oldukça önemli bir bağ bulunmaktadır. Bu bağlamda ortaya çıkan bilișsel bileșenler, konsantrasyon güçlüğü, performans beklentilerinin karșılanamaması, hata yapma dürtüsü gibi birçok durum ortaya çıkmaktadır (Kenny, Fortune ve Ackerman, 2011). Aynı zamanda gerek stüdyo kayıt aşamasında ve gerekse sahnede meydana gelen bu korkular ve kaygılar, çalınacak (icra edilecek) eserin ya da eserlerin performansına yönelik oluşacak kaygıyı tetiklemesinden dolayı ortaya olumsuz ve istenmeyen bir icra (kayıt) türü çıkabilmektedir. (Teztel ve Așkın, 2007).

\section{Sonuç ve Öneriler}

Stüdyo ortamlarında bireysel anlamda performans gösteren çalgı icracılarının kendilerini kayıt öncesinde psikolojik olarak hazırlamaları gerekmektedir. Psikolojinin rahat olmasının temel unsurlarından biri de kendine olan özgüven kavramıdır. Bu özgüveni sağlamak için de enstrüman üzerinde mutlaka egzersiz yapılmalıdır. Aynı zamanda sadece enstrüman üzerinde 
değil, genel ruh dengesini sağlamak için de vücut egzersizleri yapılmalıdır. Vücudun koordinasyonunu egzersizler aracılığıyla uyumlu hale getirmek, aynı zamanda hayat kalitesinde de belirgin bir artıș sağlamaktadır. İcra sanatçılarının öncelikle beyin ve ruh sağlığı bu anlamda önem teșkil etmektedir. Bu anlamda bakıldığında kișinin kendisine uygulamıș olduğu bir nevi "müzik terapisi" olarak da tanımlanabilen bu durumun anksiyetenin azalmasında etkili bir tedavi șekli olduğu da söylenilebilir (Bostancıoğlu ve Kahraman, 2017:153).

Vücut egzersizlerine bilimsel olarakörnek vermek gerekirse, Alexander Tekniği'nin yararlı olacağı düşünülmektedir. "Alexander Tekniği, zaman içinde fark edilmeden alışkanlık haline getirilmiş birçok hareketin engellenerek vücutta oluşan gerginlikleri rahatlatmaya yardımcı olan bir yeniden öğrenim metodudur" (Tezișçi, 2018). Özellikle de el egzersizleri bu anlamda oldukça önem teșkil etmektedir. El egzersizleri için bazı mekanik aletler de (örneğin Xtensor gibi) bulunmaktadır. Bu aletlerin yardımıyla el kasları çok fazla zorlanmaksızın harekete geçirilerek kasların açılması sağlanabilir. Aynı zamanda "kas açılması" denilen oluşumun sağlanması amacıyla uygulanacak diğer bir yöntem ise, icracının enstrümanı ile teknik ve zorlayıcı eserleri sıklıkla çalarak kas hafızasını güçlendirmesi yoluna gitmektir. Stüdyo ortamında doğrudan ses kayıt seanslarına giren müzisyenlerde sıklıkla rastlanan problemler ele alındığında çalınacak olan esere ya da eserlere yönelik egzersizlerin önceden yapılmamıș olduğu görülmektedir. Eksik egzersiz uygulaması ise stüdyo ortamındaki kayıt așaması sırasında çalgı icracılarının stres altında olmalarına yol açmaktadır. Bu nedenle de stüdyoda çalınacak olan eserin ya da eserlerin mutlaka önceden icra edilmesi ve hatta teknik açıdan zorlayıcı eserler var ise doğrudan ezberleme yoluna gidilerek çalgı üzerinde tam bir odaklanma sağlanması önerilmektedir.

Birçok çalgının icrasında pek çok fizyolojik durum meydana gelmektedir. Olușan bu fizyolojik tepkiler her icracının kendi bünyesindeki farklı tepkimeler sonucunda ortaya çıkmaktadır. Dolayısıyla da bir çalgı icra edilirken așırı zorlanmaya ve yetersiz pratik yapmaya bağlı olarak kronik ağrılar ve sakatlanmalar meydana gelebilmektedir (Brandfonbrener ve Lederman, 2002). Bu sakatlanma ve ağrıların önüne geçmek için her çalgı icracısı kendi vücudunu tanımak zorundadır. Örneğin aşırı yağı vücutlarda hareket kısıtlılığı, fiziksel uygunluğu ve genel sağlığı olumsuz yönde etkiler (Training, 1992). Dolayısıyla da icra așamasında gerekli olan esneklik ve kas rahatlığı sağlanamaz ve ortaya çıkan stres algısı ile birlikte yapılacak olan stüdyo kaydı da istenilen kalitede olmayabilir. Bu yüzden de özellikle çalgı icracılarının mutlaka sağlıklı yașam adına așırı kilodan kaçınmaları gerekmektedir. Bunun için de her sabah belirli periyodlarla yapılacak olan vücut egzersizleri bu anlamda çok yararlı olacaktır.

Stüdyo ortamında yapılacak olan ses kayıt seanslarına hazırlı sürecinde ise çalgı icracılarının uyku düzeninin de kontrol altına alınması gerekmektedir. Uykusuzluk ve diğer uyku problemleri günümüz çalgı icracılarında sıklıkla görülen ciddi bir sorundur. Bu sorun, bireylerde anksiyeteye ve huzursuzluğa yol açtığı için de çalgı icrası sırasında 
dikkat dağınıklığına neden olmaktadır. Özellikle de gece uykusu (melatonin hormonunun salgılandığı evre) icracılar için önem arz etmektedir. Gece saat 02:00 - 04:00 arasında beynin salgılamış olduğu melatonin hormonun en üst düzeye çıkması nedeniyle bu aralıkta alınan uyku vücudu dengeleyerek stres algısının da en aza indirgenmesine yardımcl olacaktır. Fakat genelde müzisyenlerin gece hayatlarının olması ve genellikle de bu saatlerde uyanık olduklarından dolayı melatonin hormonunun salgilanmasında çeșitli aksaklıklar meydana gelmektedir. Dolayısıla da çoğu müzisyende uykusuzluk sorunu ile birlikte ortaya çıkan anksiyete ve stres bozuklukları, bu insanların sanatsal kariyerleri boyunca her zaman gizli bir düșman olmaya devam etmektedir.

Anksiyete ve performans kaygısını yaşayan çalgı icracılarının maruz kaldıkları diğer bir durum ise "ortam" fobisidir. Pek çok icracıda görülen bu fobi, alıșmıș oldukları kendi ortamlarının dışına çıktıkları zaman nüksetmektedir. İcracılar, genellikle kendi evlerinde ya da rahat ettikleri belirli bir ortamda çalgılarına saatler boyunca çalışarak söz konusu ortamı kendileri için uygun, elverișli ve huzurlu bir mekân olarak görebilmektedirler. Bu yüzden de çoğu çalgı icracısından sıklıkla șu söz duyulur: "Kendi evimde enstrümanımı hatasız bir șekilde çalıyorum ancak her nedense stüdyo ortamına geldiğim zaman takılıyor ve hata yapıyorum." Bu fobiyi yenmek için uygulanması gereken en basit yöntem ise, çalgı çalınacak olan söz konusu ortamda (stüdyo, konser salonu vs.) ses kayıt seansı öncesinde mutlaka egzersiz yapmaktır. Hatta bu egzersiz uygulamalarından sonra hangi eser ya da eserler icra edilecekse bu egzersiz pratiği sürecine onların da dahil edilmesi müzisyenlere ciddi anlamda yarar sağlayacaktır. Böylelikle söz konusu icra mekânında çalgı ile birlikte geçirilen zaman dilimi sayesinde o ortam icracılara artık yabancı gelmeyecek ve psikolojik olarak da onların anksiyeteden bir nebze de olsa uzaklașmalarını sağlayacaktır.

Stüdyo ortamında gerçekleștirilen kayıtlar, genellikle kulaklıktan metronom sesi alınarak ve kanal kaydı șeklinde çalınarak yapılmaktadır. Bu durumda birçok çalgı icracısı stres altına girmekte ve anksiyeteye de bağlı olarak kendisini kaygıl hissetmektedir. Yanlıs yapma ve metronom kaçırma olarak tabir edilen durumun icracı tarafından düșünülmesi, - an stüdyoda kayıt altına alınacak olan esere tam olarak odaklanamaması ile sonuçlanabilmektedir. Bu durumu bertaraf etmek için çalgı icracılarının normal etütlerini ve egzersizlerini mutlaka metronom eșliğinde çalıșmaları gerekmektedir. Genelde metronom ile çalışmayan çalgı icracılarının stüdyo performanslarında aksaklık meydana gelebildiği gibi, bu aksaklıkla bașa çıkamama durumunun kaçınılmaz bir sonucu olarak yine anksiyete sorunları görülmektedir.

Günümüzün çağdaș müzik teknolojilerini de göz önüne aldığımızda, ses kayıt seanslarının artık home studio olarak adlandırdığımız ve evlerimizin bir odasına kurmuş olduğumuz küçük ölçekli stüdyo ortamlarında gerçekleștirildiğine tanıklık etmekteyiz. Dolayısıyla da çalgı çalan müzisyenlerin stüdyo kayıt tekniği doğrultusunda kendilerini ve icra pratiklerini geliștirmelerinin gerekliliği bu bağlamda büyük önem tașımaktadır. Gerek resmi müzik eğitim kuruluşlarında ve gerekse müzik eğitimi 
veren özel kurumlarda çalgı icracısı olarak yetiștirilen öğrencilerin bu duruma uyum sağlamaları zorunluluğu nedeniyle verilecek olan çalgı eğitimi derslerinin "bireysel performans" ve "anksiyete" ilișkisine yönelik olarak geliștirilmiş bilimsel nitelikteki çeșitli çözüm yöntemlerini de içermelerinin bireylere ciddi anlamda katkı sağlayacağı düşünülmektedir.

Stüdyo kayıt performansları sırasında çalgı icracılarında ortaya çıkan psikolojik durumların saptanması ve kesin birer tanı haline getirilmeleri için tıbbi anlamda mutlaka destek alınması gerekmektedir. Böylelikle bu sorunun üstesinden gelinmesinde daha etkili ve kalıcı çözümlerin ortaya koyulması da mümkün olacaktır. Sırf müzik eğitmenleri ile söz konusu anksiyete ve performans kaygısı sorunlarının üstesinden gelinemeyeceği olgusu, bu bağlamda yapılan bilimsel araștırmalar sayesinde de desteklenmektedir. Profesyonel anlamda ses kayıtları yapan çalgı icracılarının kendi psikolojik durumlarının psikiyatri bilimi alanında uzman olan bir hekim tarafından incelenerek tedavi yoluna gidilmesi sayesinde söz konusu çalgı icracılarının mesleki hayatlarının da normal bir düzeye gireceği öngörülmektedir.

Öte yandan küçük yaşlardan itibaren alınan çalgı eğitimleri ve bu doğrultuda gerçekleștirilen çalgı icra deneyimleri, bireyin olgunluk çağına eriștiğinde daha rahat bir performans sergilemesine olanak sağlayabilmektedir. $\mathrm{Bu}$ anlamda dünyaca ünlü kemancı Midori Goto'nun sanatsal deneyimi ve birikimi çalgı icracıları için bir nevi kılavuz niteliğindedir. Erken yaşlarında baskı ortamını yașamış olan müzisyen çocuklar, zaman geçtikçe bu durumu normal bir olaymıș gibi algılayarak üzerlerindeki stresi atmaktadırlar. Dolayısıyla da çalgı eğitimine erken yașta bașlamanın yadsınamaz düzeydeki önemi ile gerekliliği bu bağlamda çok daha iyi anlaşılmakta ve açıklık kazanmaktadır.

Türkiye'de çalgı icracılarının stüdyo performansları sırasında yașadıkları anksiyete problemlerinin çözümü amaciyla daha fazla bilimsel çalıșmaya intiyaç olduğu, bu bağlamda gerçekleștirilen çeșitli araștırmalar ile literatür taramalarının bir sonucu olarak anlașılmıștır. Bu tarz çalıșmaların söz konusu literatür ekseninde daha kapsaml ve detaylı bir șekilde incelenerek geliștirilmesi gerekmektedir. Türkçe yayın eksikliğinin özellikle de bu alanda önemli bir boșluk olduğu ve bu boșluğun doldurulması adına gerek akademik ve gerekse bilimsel anlamda yeni çalıșmalar yapılmasının alana önemli ölçüde katkı sağlayacağı düşünülmektedir.

\section{Kaynakça}

Anksiyete, (2021). 30 Nisan 2021 tarihinde, http://www.etimolojiturkce. com/kelime/anksiyete.

Aydın, B., İşgörür, Ü. (2018). Ortaokul ve Lise Düzeyinde Öğrenim Gören Konservatuvar Öğrencilerinin Müzik Performans Kaygılarının Çeșitli Değișkenlere Göre İncelenmesi. Afyon Kocatepe Üniversitesi Akademik Müzik Araștırmaları Dergisi , 4 (7), 1-20.

Bostancioğlu, B , Kahraman, M . (2017). Sanat Terapisi Yönteminin Ve Tekniklerinin Sağlık - İyileștirme Gücü Üzerindeki Etkisi. Beykoz Akademi Dergisi, 5 (2), 150-162. 
Brotons, M. (1994). Effects of Performing Conditions on Music Performance Anxiety and Performance Quality. Journal of Music Therapy. 31(1). 63-80.

Çırakoğlu, O. C. (2013). Sahnedeki Düșman: Müzisyenlerde Performans Kaygısı Üzerine Bir Gözden Geçirme, Türk psikoloji yazıları, 16(32), 95-104.

Eğilmez, H. O., Aytekin, N. T. ve Dirican, M. (2013). Coping with the performance anxiety among music education students: A method trial. Asian Journal of Social Sciences \& Humanities, 2, 65-173.

Gidergi Alptekin, A. (2012). Müzik performans anksiyetesi. Trakya Üniversitesi Sosyal Bilimler Dergisi, 14, 137-148.

Kabakçı, C. (2016). Sahne Performansı Kaygısında Farkındalık ve Mücadele, Sahne ve Müzik Eğitim Araștırma Dergisi, Sayı:3.

Kafadar, A. (2009). Piyanistler Örneğinde Müzisyenlere Özgü Performans Anksiyetesi, Güzel Sanatlar Enstitüsü Müzik Anasanat Dalı Yüksek Lisans Tezi, Dokuz Eylül Üniversitesi, İzmir.

Kenny, D.T., Fortune, J.M. ve Ackermann, B., (2011). Predictors of music performance anxiety during skilled performance in tertiary flute players. Psychology of Music, 41, 306-328.

Kenny, T. Dianna., Davis, Pamela., Oates, Jenni. (2004). Music performance anxiety and occupational stress among opera chorus anxiety and their relationship with state and trait anxiety and perfectionism, Journal of Anxiety
Disorders, 18(6), 757-777.

Konsantrasyon Bozukluğu Nedir, Çözümü Nedir, (2021). 1 Mayıs 2021 tarihinde, https: / / www. isbank.com.tr/blog/ konsantrasyon-bozuklugu-nedir.

Koyuncu, A., Binbay, Z. (2014). Sosyal Anksiyete Bozukluğu ve Dikkat Eksikliği Hiperaktivite Bozukluğu Birlikteliği Psikiyatride Güncel Yaklașımlar - Current Approaches in Psychiatry, Gale Academic OneFile, 6(1), 10-21.

Cemai, M. (2017). Müzik Bölümü Lisans Öğrencilerinde Performans Kaygısına Neden Olan Faktörlerin Belirlenmesi. Yüksek Lisans Tezi, Hacettepe Üniversitesi Sağlık Bilimleri Enstitüsü, Ankara.

Parncutt, R., McPherson, G. eds., (2002). Science and Psychology of Music Performance, 48, Oxford University Press, New York.

R. Parncutt., G. E. McPherson, (2002). The Science and Psychology of Music Performance, Oxford University Press, 47-61.

Salmon, P. (1990). A Psychological Perspective on Musical Performance Anxiety" - a Review of the Literature, Medical Problems of Performing Artists, 5(1), 1-11.

Seligman, M. E., Walker, E. F., Rosenhan, D. L. (1989). Abnormal psychology. 4th. New York: W.W. Norton \& Company.

Steptoe, A., (1989). Stress, Coping and Stage Fright in Professional musicians, Psychology of Music, 17, 2-11. 
Tezișçi, P . (2018). Alexander Tekniği'nin Temel Uygulama ilkeleri Ve Çalıșma Yöntemleri. Afyon Kocatepe Üniversitesi Akademik Müzik Araștırmaları Dergisi, 4 (7), 65-80.

Teztel, G. Așkın, C., (2007). Sahne Heyecanının Türk Müzisyenler Arasındaki Yaygınlığı ve Çözüm Yöntemleri. iTü Sosyal Bilimler Dergisi, (4)2, 3-10.

Tokinan, B. Ö., Kenny, T. (2013). Müzik Performans Kaygısı Envanterini Türkçe'ye Uyarlama Çalıșması. Ahi Evran Üniversitesi Kırșehir Eğitim Fakültesi Dergisi (KEFAD), 14(1), 53-65.

Training, P. F. (1992). US Army field manual (FM). Headquarters, Department of the Army, Washington DC, 20-21.

Valentine, E. (2003). Musical Performance, A Guide to understanding. Ed. John Rink. Londra. Cambridge University Press, 168-182.

Weisblatt, S. (1986). A psychoanalytic view of performance anxiety, Medical Problems of Performing Artists, 1(2), 6467.

Williamon, A (Ed.). (2004). Musical Excellence: Strategies and Techniques to Enhance Performance. Oxford: Oxford University Press.

Wilson Glenn. D., Roland David. (2002). Performance Anxiety. Oxford. 
The negative effects of performance concern and anxiety syndrome on the instrument performers' success encountered on studio recording environments

\section{Extended Abstract}

Considering today's music industry and its development, it is seen that instrument performers have a great importance in both album recordings and concert performances. Instrument players spend a lot of time in order to present their individual performances in the best way and to play them flawlessly. However, they cannot convey the performance that emerges at the end of this time they spend in studio environments at the desired level. The reason for these problems experienced by the instrument performers may be their own anxiety and uneasiness and these can negatively affect their performance too. This situation, which stands out as one of the biggest problems of professional or amateur performers, is generally referred to as "Performance Anxiety". Instrument performers are expected to play the notes flawlessly, especially during the sound recording sessions in the studio environment. While this expectation puts pressure on the musicians playing the instrument, it also creates an obvious uneasiness over them. In this sense, even if the performers have a professional identity, they may face unexpected negative situations. These negative situations may be that it is the wrong note presses that occur momentarily on the album tracks recorded during the performance of a work or in the studio or the inability to cope with the urge to read the wrong note due to stress. Studio environments are generally the areas where the performers are alone with their instruments and reflects all their musical knowledge and experience with their performances. Therefore, in these areas, the musicians should feel comfortable and perform their performance without any pressure. Otherwise, when musicians who will play any instrument feel stressed and have a negative mindset, it is inevitable that they will have deficiencies in their performances in the studio. Every musician seeks an environment where he is at peace with his instrument and a stress-free space. Whenever they feel free and comfortable, the efficiency in their instrument performances is at the highest level. In this context, the performance concerns of musicians while playing the instrument should be handled behaviorally, cognitively and physiologically. Within the scope of this research, each of these cases was tried to be explained in detail. In this study, the formation processes of the concept of anxiety, when emerges by considering the mood of the instrument performers from a psychological point of view, are given in detail. Accordingly, the subject at which stages Social Anxiety Disorder (SAD) and Attention Deficit Hyperactivity Disorder (ADHD) occur has been revealed with their scopes. The "excitement" that arises in the loss of performance seen in musicians and especially instrument performers is sometimes perceived differently. Therefore, it is very important to distinguish the difference between excitement and anxiety. Within the scope of this study, some suggestions were made by trying to reveal the difference between the concept of excitement and anxiety. Information about correct postures, which is one of the other ways to get good results in studio performances, is also included. Muscle and joint pains caused by incorrect postures, which is one of the biggest handicaps of instrument performers, adversely affect the performance that will emerge. This effect, on the other hand, makes the musicians uneasy over time and leads them to a state of psychological warfare. The complex structures revealed by playing an instrument are examined in detail, and the anxiety problems caused by the results are also among the subjects of this research. The aim of this study is to reveal the problems that instrument performers encounter during the high level of error-free performance sessions expected from them in studio environments and to find solutions to these problems. At the same time, a survey model, one of the qualitative research methods, was used in this study in order to collect data on the subject. The data obtained as a result of the research were interpreted by using the descriptive analysis method and various suggestions were made in this context.

\section{Keywords}

instrument performance, studio recording environment, performance anxiety, anxiety. 
